\title{
Identification of two novel cytolysins from the hydrozoan Olindias sambaquiensis (Cnidaria)
}

\author{
Vidal Haddad Junior ${ }^{2}$, Fernando Zara', Sergio Marangoni ${ }^{3}$, Daniela de Oliveira Toyama ${ }^{4}$, \\ Alex Jardelino Felizardo de Souza', Simone Cristina Buzzo de Oliveira ${ }^{1,2}$ and Marcos Hikari Toyama ${ }^{1,5^{*}}$
}

\begin{abstract}
Background: Although the hydrozoan Olindias sambaquiensis is the most common jellyfish associated with human envenomation in southeastern and southern Brazil, information about the composition of its venom is rare. Thus, the present study aimed to analyze pharmacological aspects of $O$. sambaquiensis venom as well as clinical manifestations observed in affected patients. Crude protein extracts were prepared from the tentacles of animals; peptides and proteins were sequenced and submitted to circular dichroism spectroscopy. Creatine kinase, cytotoxicity and hemolytic activity were evaluated by specific methods.
\end{abstract}

Results: We identified two novel cytolysins denominated oshem 1 and oshem 2 from the tentacles of this jellyfish. The cytolysins presented the amino acid sequences NEGKAKCGNTAGSKLTFKSADECTKTGQK (oshem 1) and NNSKAKCGDLAGWSKLTFKSADECTKTGQKS (oshem 2) with respective molecular masses of $3.013 \mathrm{kDa}$ and $3.375 \mathrm{kDa}$. Circular dichroism revealed that oshem 1 has random coils and small a-helix conformation as main secondary structure whereas oshem 2 presents mainly random coils as its main secondary structure probably due to the presence of W (13) in oshem 2. The hemolysis levels induced by oshem 1 and oshem 2 using a peptide concentration of $0.2 \mathrm{mg} / \mathrm{mL}$ were, respectively, $51.7 \pm 6.5 \%$ and $32.9 \pm 8.7 \%(n=12$ and $p \leq 0.05)$. Oshem 1 and oshem 2 showed significant myonecrotic activity, evaluated by respective CK level measurements of $1890.4 \pm 89$ and $1212.5 \pm 103$ ( $n=4$ and $p \leq 0.05$ ). In addition, myonecrosis was also evaluated by cell survival, which was measured at $72.4 \pm 8.6 \%$ and $83.5 \pm 6.7 \%$ ( $n=12$ and $p \leq 0.05$ ), respectively. The structural analysis showed that both oshem 1 and oshem 2 should be classified as a small basic hemolytic peptide.

Conclusion: The amino acid sequences of two peptides were highly similar while the primary amino acid sequence analysis revealed W (22th) as the most important mutation. Finally oshem 1 and oshem 2 are the first cytolytic peptides isolated from the Olindias sambaquiensis and should probably represent a novel class of cytolytic peptides.

Keywords: Olindias sambaquiensis, Hemolytic, Myonecrosis, Cytotoxicity, Cytolysin, Cnidaria venom

\section{Background}

The phylum Cnidaria is subdivided into five classes. Some species are important in human medicine since they can cause severe envenomation by the injection of venom through specialized cells. In Brazil, these organisms are included in the Hydrozoa, Scyphozoa and Cubozoa classes $[1,2]$. The class Hydrozoa has two species frequently associated with human envenomation: the Portuguese man-

\footnotetext{
* Correspondence: mhtjpn@yahoo.com

'São Paulo Experimental Coast Campus, São Paulo State University (UNESP -

Univ Estadual Paulista), São Vicente, São Paulo State, Brazil

${ }^{5}$ UNESP, Campus do Litoral Paulista, Unidade São Vicente, Praça Infante D.

Henrique, s/n, São Vicente, SP CEP 11330-900, Brasil

Full list of author information is available at the end of the article
}

of-war (Physalia physalis) and Olindias sambaquiensis (Figure 1), the latter being related to the majority of accidents in the most populated regions of Brazil [1,2]. Like the other cnidarians, they present stinging cells equipped with small organelles known as nematocysts that contain small threads ejected along with the venom when stimulated mechanically or chemically [3]. Furthermore, nematocysts are found throughout the body of the cnidarians and not just in their tentacles [4-6].

Olindias sambaquiensis ("relojinho" in the Portuguese language), is a small hydrozoan jellyfish that provokes mild accidents on the southeastern and southern Brazilian coast where it is commonly found in winter and autumn $[1,2,7]$. Despite the medical relevance and abundance of 


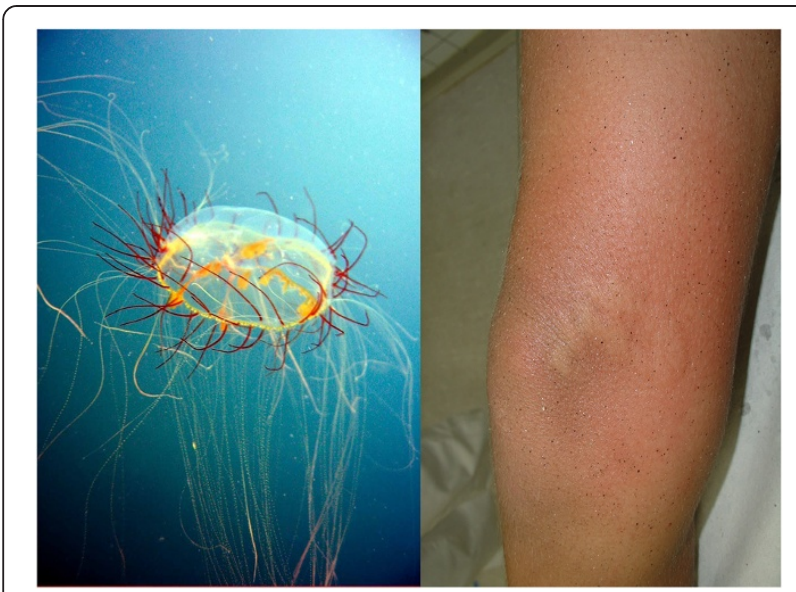

Figure 1 Olindias sambaquiensis and a typical lesion in a human. Photos: Álvaro E Migotto and Vidal Haddad Junior.

this species in Brazil, there are not any studies characterizing its venom biochemically. The present work aimed to report the structural and biological characterization of hemolytic proteins from the nematocysts of Olindias sambaquiensis.

\section{Methods}

The jellyfish were collected off the São Vicente beach (latitude 235ำ $47^{\prime \prime}$ - South, longitude 46²3'31" - West) and their tentacles were then subjected to three freezethaw cycles. After the last freeze-thaw cycle, the solution was centrifuged at 20,000 g for 60 minutes at $4^{\circ} \mathrm{C}$. Crude protein extracts were prepared from the tentacles removed from the jellyfish body using forceps and immediately immersed in an ice-cold $0.1 \%$ trifluoroacetic acid (TFA). The supernatant was recovered and filtered through a $0.45-\mu \mathrm{m}$ filter, followed by a second ultrafiltration using a $0.22-\mu \mathrm{m}$ filter.

The desired fraction was then lyophilized and the resulting peptides were subjected to hemolysis assay on freshly prepared human erythrocytes.

Protein sequencing was performed as previously described by Oliveira et al. [8]. Briefly, two milligrams of the purified protein was dissolved in $200 \mu \mathrm{L}$ of a $6 \mathrm{~mol} / \mathrm{L}$ guanidine chloride solution (Merck, Germany) containing $0.4 \mathrm{~mol} / \mathrm{L}$ of Tris- $\mathrm{HCl}$ and $2 \mathrm{mmol} / \mathrm{L}$ of EDTA (pH 8.15). Nitrogen was blown over the top of the protein solution for 15 minutes, after which the protein solution was reduced with DTT $(6 \mathrm{M}, 200 \mu \mathrm{L})$ and subjected to a second incubation under a nitrogen atmosphere for 90 minutes. After this incubation time, $80 \mu \mathrm{L}$ of iodoacetic acid was added to the solution (50 $\mathrm{mM}$ of cold iodoacetic and carboxymethylated ${ }^{14} \mathrm{C}$-iodoacetic acid), followed by a third incubation under a nitrogen atmosphere after which the reaction tube was sealed. To remove excess reagent and to purify the peptides, we used a preparative $\mathrm{C} 5$ reverse phase column.

Circular dichroism (CD) spectroscopy: the purified peptide was dissolved in $10 \mathrm{mM}$ sodium phosphate $\mathrm{pH} 7.4$ and the solution was adjusted to final protein concentration of $10 \mu \mathrm{M}$. After centrifugation at $4500 \times g$ for five minutes, samples were transferred to a $1 \mathrm{~mm}$ path-length quartz cuvette. Circular dichroism spectra in the wavelength range 185-300 $\mathrm{nm}$ were acquired in-house on a J720 spectropolarimeter (Jasco Corp., Japan) using a bandwidth of $1 \mathrm{~nm}$ and a response time of $1 \mathrm{~s}$. Data collection was performed at room temperature. With a scanning speed of $100 \mathrm{~nm} / \mathrm{min}$, a total of nine scans was accumulated for each sample and all the spectra were corrected by subtraction of buffer blanks.

The release of creatine kinase (CK) from damaged muscle cells was followed by use of the Kit 47-UV (SigmaAldrich Co., USA) to measure the enzyme activity in mouse plasma. For this determination five groups of mice (18-22 g) were injected in the right gastrocnemius muscle with $50 \mu \mathrm{L}$ of $0.5 \mathrm{mg}$. $\mathrm{mL}^{-1}$ toxins $(\mathrm{n}=4)$ while the control group received PBS. For the CK determination in plasma, the animals were lightly anesthetized with halothane immediately before and three hours after toxin or PBS injection for blood collection according to the guidelines for the care and use of laboratory animals [9].

Mice were bled from the tail three hours after injection and blood was collected into heparinized tubes, with one aliquot being used for CK determination. Plasma was separated by centrifugation and stored at $4^{\circ} \mathrm{C}$ for subsequent determination of CK activity. The procedure for the measurement of CK activity was conducted following the instructions of the kit (Kit 47-UV, Sigma Chemical Co., USA). Enzyme activity is reported as international units per liter $(\mathrm{U} / \mathrm{L})$, in which $1 \mathrm{U}$ is the amount that catalyzes the transformation of $1 \mu \mathrm{mol}$ of substrate at $25^{\circ} \mathrm{C}$. The cytotoxicity assay was conducted according to Passero et al. [10] with toxins (or PBS as control) incubated with cells for 60 minutes. Cytotoxicity of the toxins from the Olindias sambaquiensis in J774 cells in culture was assayed using 3-(4,5-Dimethylthiazol-2-yl)-2,5-diphenyl tetrazolium bromide (MTT). Briefly, cells in 96-well plates (106 macrophage/well) in culture medium (RPMI 1640) for 48 hours at $35^{\circ} \mathrm{C}$ and $5 \% \mathrm{CO}_{2}$ were incubated with various toxin concentrations ranging from 0.78 to $100.00 \mu \mathrm{g} /$ well for 48 hours. The cells were then washed and incubated with MTT for four hours, followed by SDS with $10 \% \mathrm{HCl}$ for the determination of formazan conversion, which was monitored by absorbance at $595 \mathrm{~nm}$. This experiment was carried out in triplicate.

Hemolytic activity of the toxin was measured quantitatively in terms of attenuance on human red blood cells $(\mathrm{RBC})$ at room temperature using a Spectramax Microtiter ${ }^{\circledast}$ plate reader (Molecular Devices, USA). Human 
blood, freshly collected with heparin, was centrifuged to remove the buffy coat, and the erythrocytes obtained were washed three times in $0.85 \%$ saline and stored at $4{ }^{\circ} \mathrm{C}$. Toxins at desired concentrations were added in the first well to erythrocyte buffer $(140 \mathrm{mM} \mathrm{NaCl}, 10 \mathrm{mM}$ Tris$\mathrm{HCl}, \mathrm{pH} 7.4)$, and then serially diluted two-fold. RBCs $(100 \mu \mathrm{L} ; \mathrm{D} 630=0.5)$ in erythrocyte buffer were added to the toxins, and hemolysis was monitored by measuring attenuance at $630 \mathrm{~nm}$ for 20 minutes at room temperature. The final volume was $200 \mu \mathrm{L}$ per well. The hemolysis percentage was determined at the end of the assay using the following equation of Malovrh et al. [11]:

$$
\text { Hemolysis (\%) } \frac{(D \max -D o b s)}{D \max -D \min } \times 100
$$

in which Dobs was the measured attenuance in the well after 20 minutes and Dmax is the maximal attenuance by distilled water and Dmin is the minimal attenuance by buffer used in the test. For this assay we firstly determined the hemolytic CI50 values for oshem 1 and oshem 2 , which were $324 \mu \mathrm{g}$ and $198 \mu \mathrm{g}$, respectively.

The animal utilization was approved by the Committee for Ethics in Animal Experimentation of the Institute of Biology, UNICAMP, certificate number 1320-1. We utilized Swiss mice supplied by CEMIB, the Multidisciplinary Center for Biological Research of UNICAMP.

\section{Results and discussion}

Accidents involving the hydrozoan Olindias sambaquiensis are common in South America and may provoke
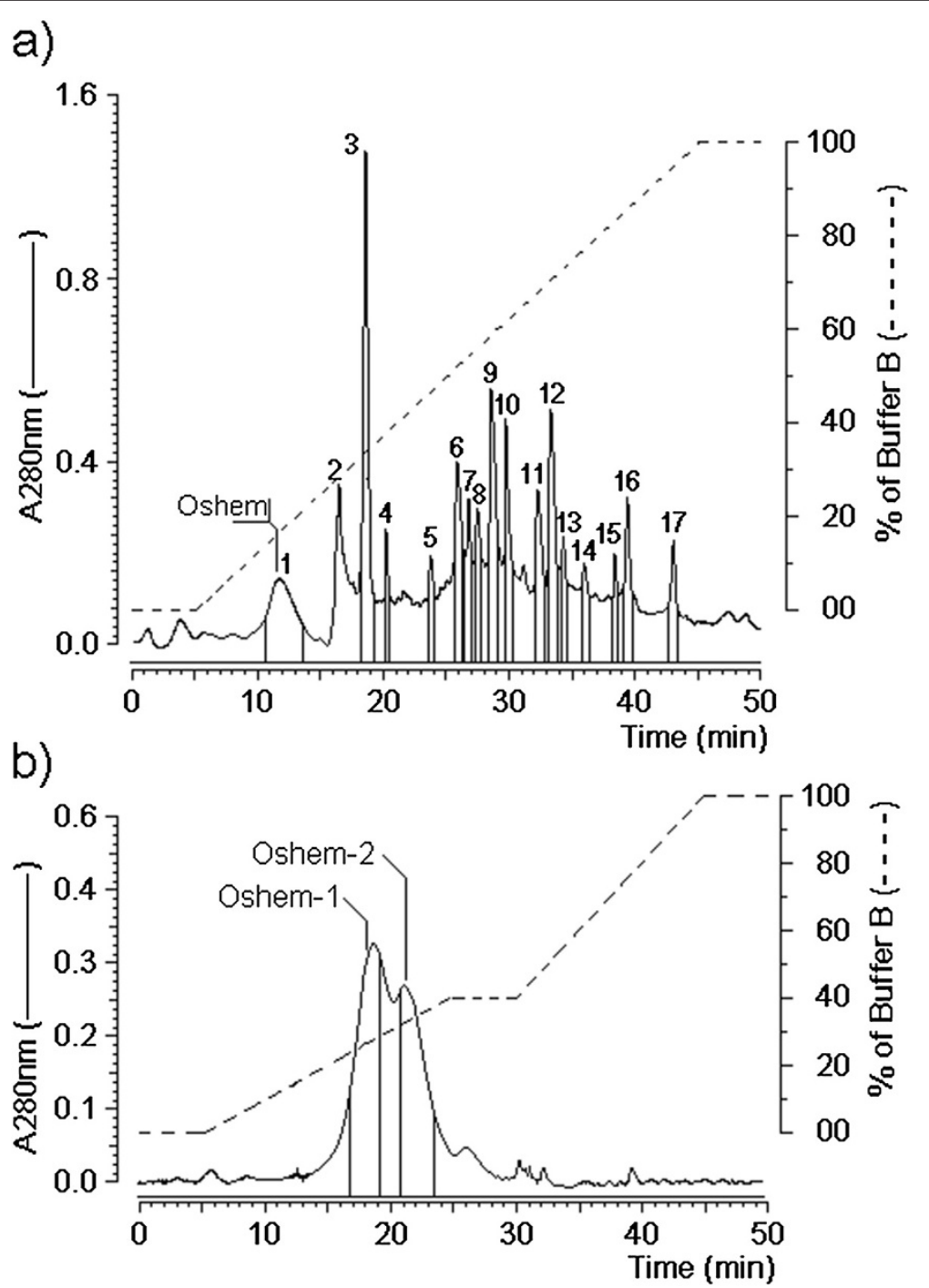

Figure $\mathbf{2}$ Initial fractionation of protein extract obtained after addition of TFA on the Olindia sambaquiensis aqueous extract. (a) The main hemolytic fraction was named oshem. (b) Re-purification of oshem by C18 reverse phase HPLC created two main fractions, oshem 1 and oshem 2. 
dermatitis, skin lesions, edema and pain. Olindias sambaquiensis poisoning is characterized as moderate to severe, which can lead to cardiovascular complications including cardiopulmonary arrest. Despite its clinical importance and the seriousness of symptoms observed, this is the first study of the biochemical characterization and isolation of toxic components from Olindias sambaquiensis.

The protocol used for this work essentially followed the methods used for Bunodosoma caissarum [12] and Phyllorhiza punctata [13]. The crude extract from Olindias sambaquiensis revealed the presence of at least 17 fractions, of which only one fraction, denominated oshem, showed a moderate hemolytic activity (Figure 2a), and was subjected to novel fractionation on C18 reverse chromatography using non-linear gradient of buffer B $(66.6 \%$ of acetonitrile in $0.1 \%$ TFA) at a constant flow rate of $1.0 \mathrm{~mL} / \mathrm{min}$. Under this condition, we purified two isoforms from oshem that were designated oshem 1 and oshem 2 (Figure 2b).

Sea anemone toxins comprise mainly proteins and peptides that are cytolytic or neurotoxic with their potency varying according to the structure and action site, and are efficient at targeting different animals, such as insects, crustaceans and vertebrates. Summarily, the cnidarians venom includes 3.5 to $6.5 \mathrm{kDa}$ voltage-gated sodium (NaV) channels toxins and 3-5 kDa voltage-gated potassium (KV) channel toxins and $\sim 20 \mathrm{kDa}$ pore-forming toxins [14]. In the case of pore-forming toxins, there are three other less frequent classes of toxins that can be classified as: group I, which consists of peptides from 5 to $8 \mathrm{kDa}$; group III with a molecular mass of $80 \mathrm{kDa}$; and the pore-forming toxins with phospholipase A2 activity and molecular mass around 20 to $40 \mathrm{kDa}$ [15]. Toxins oshem 1 and oshem 2 contain hydrophilic low-molecular-weight peptides, and can be classified as group I toxins, which are peptides of 5 to $8 \mathrm{kDa}$, following the classification established by Anderluh and Macek [15].

The N-terminal amino acid sequencing of oshem 1 and oshem 2 was determined after reduction. Both were subjected to automatic amino acid sequencing using a Procise ${ }^{\bullet}$ Protein Sequencer (Applied Biosystems, USA). The phenylthiohydantoin $(\mathrm{PTH})$ derivatives of the amino

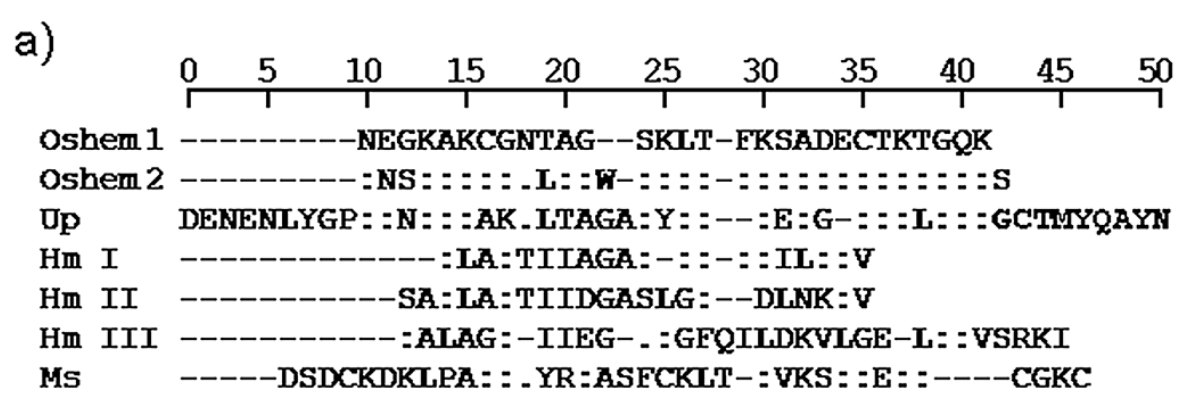

b)

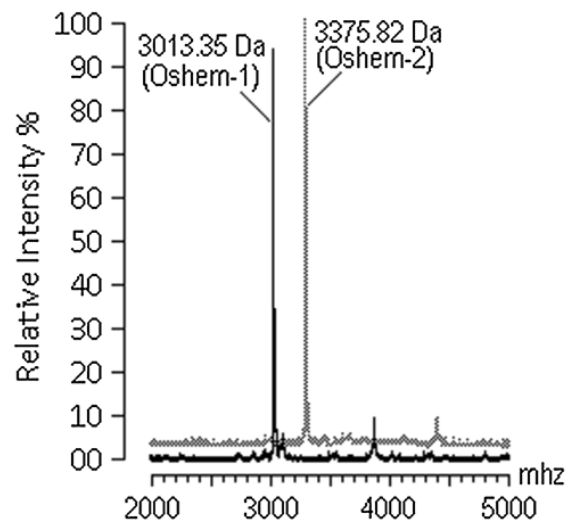

c)

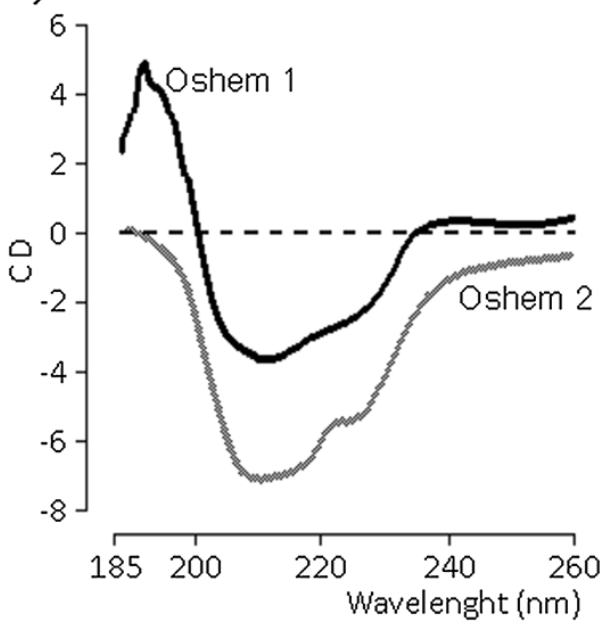

Figure 3 Aminoacid sequences, mass spectrometry and CD spectra results of Oshem 1 and Oshem 2. (a) Complete amino acid sequences of oshem 1 and oshem 2 are compared with other hemolytic and cytolysin isolates from Urticina piscivora (Up), Heteractis magnifica (magnificalysin I, magnificalysin II and magnificalysin III) and Metridum senile (Ms). (b) Mass spectrometry results of oshem 1 and oshem 2 with respective molecular masses of $3.013 \mathrm{kDa}$ and $3.375 \mathrm{kDa}$. (c) CD spectra of oshem 1 and oshem 2 in the wavelength range of 185-300 nm were acquired in-house with a J720 spectropolarimeter (Jasco Corp., Japan) using a bandwidth of $1 \mathrm{~nm}$ and a response time of $1 \mathrm{~s}$. 
acids were identified by an Applied Biosystems model 450 microgradient PTH analyzer. (Figure 3a) and a 50\% amino acid identity with Up (Urticina piscivora). The molecular masses of oshem 1 and 2 were measured according to the description of Toyama et al. [16], and found to be, respectively, $3.013 \mathrm{kDa}$ and $3.375 \mathrm{kDa}$ (Figure $3 \mathrm{~b}$ ). The circular dichroism showed that oshem 1 presents an $\alpha$-helix structure not found in oshem 2, which revealed mainly the presence of random coil structures (Figure 3c) while the most important shifts observed were L (10th) and W (13th), which should be involved in modification of the secondary structure between oshem 1 and oshem 2 . This structural replacement from oshem 1 to oshem 2 induced a significant modification in the secondary structure of these toxins. The structural contents of oshem 1 comprise: percentage (\%) by $\mathrm{CD}$ analysis of $\alpha$-helix 33 ; $\beta$-sheet 48 and random coils 19; whereas the secondary structural contents of oshem 2 are: percentage (\%) by CD analysis of $\alpha$-helix $04 ; \beta$-sheet 68 and random coils 28.

Data collection was performed at room temperature, with a scanning speed of $100 \mathrm{~nm} \cdot \mathrm{min}^{-1}$. Nine scans were accumulated for each sample whereas all spectra were corrected by subtraction of buffer blanks. The CD spectra are expressed as theta machine units in millidegrees.

The hemolytic activity levels of oshem fraction before its fractionation in oshem 1 and oshem 2 was evaluated at $12.4 \pm 3.4 \%(\mathrm{n}=12$ and $\mathrm{p} \leq 0.05)$, whereas the levels of oshem 1 and 2 were $51.7 \pm 6.5 \%$ and $32.9 \pm 8.7 \%(n=12$ and $\mathrm{p} \leq 0.05$ ), respectively, and the hemolytic potency of oshem 1 was two-fold less than that of $\alpha$-hemolysin (Figure 4a). CK level after the injection of oshem was $759.50 \pm 34 \quad(\mathrm{n}=4, \mathrm{p} \leq 0.05)$, whereas treatment with oshem 1 or 2 increased CK levels by $1890.4 \pm 89$ and $1212.50 \pm 103$, respectively $(\mathrm{n}=4, \mathrm{p} \leq 0.05)$ (Figure $4 \mathrm{~b})$. Cytotoxicity assay results were expressed as percentage of viable cells. Macrophage cell viability was moderately decreased in the presence of whole oshem fraction before its fractionation in oshem 1 and oshem 2 was $92.4 \pm 3.4 \%$ $(\mathrm{n}=12, \mathrm{p} \leq 0.05)$. For oshem 1 and 2 the values were $72.4 \pm 8.6 \%$ and $83.5 \pm 6.7 \%(\mathrm{n}=12$ and $\mathrm{p} \leq 0.05)$, respectively (Figure $4 \mathrm{c}$ ). Cytolysins adopt a stable soluble structure, which undergoes a conformational change when brought into contact with a membrane, leading to an active, membrane-bound form that inserts spontaneously into the membrane [17-19]. The helix structure of oshem 1 appears crucial for exerting its full hemolytic activity, while the presence of W (22th) virtually destroyed its helix structure but did not abolish its hemolytic, myonecrotic or cytotoxic effect. The CD structure of oshem 2 showed the presence of random coil and beta-sheet structure, raising the possibility that beta sheet may make an important structural contribution to the biological and pharmacological activity of oshem 1 and 2 .

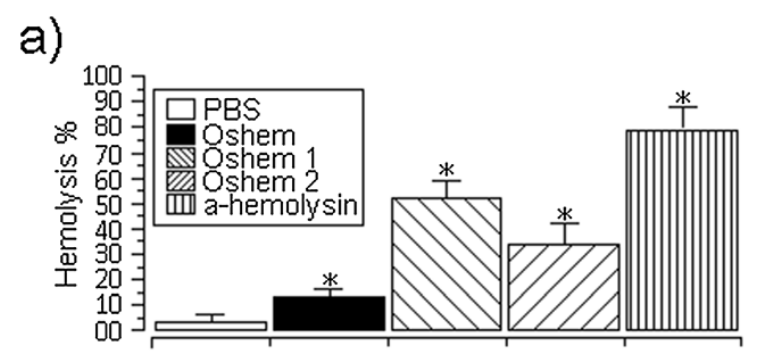

b)
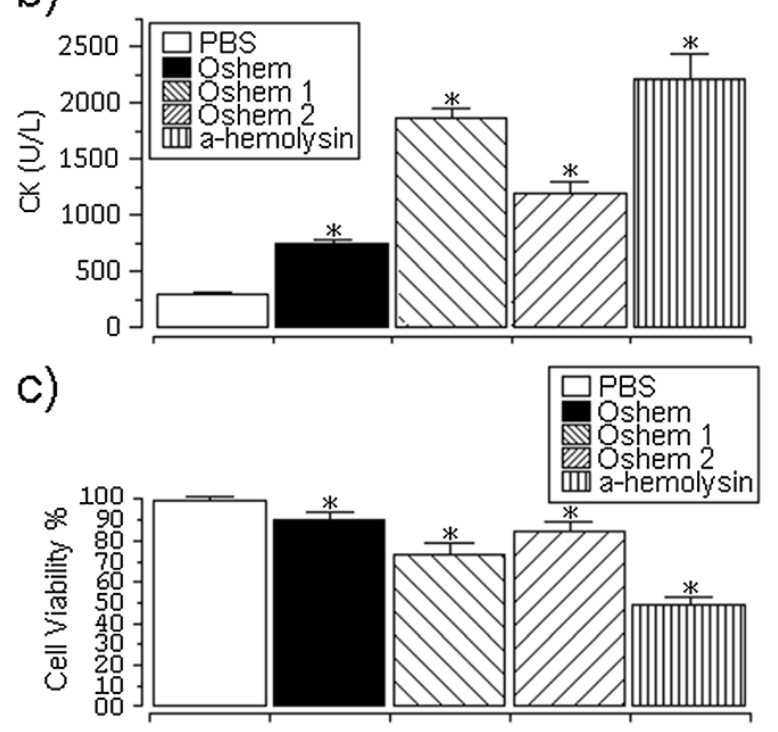

Figure 4 Hemolytic effect of oshem, oshem 1 and oshem 2 and alpha-hemolysin compared with alpha-hemolysin of Staphylococcus aureus. (a) The hemolytic effect on the hRBC at $0.3 \mu \mathrm{mol}$ of oshem, oshem-1 and oshem- 2 and a-hemolysin (these results expressed as hemolysis/\% were compared to hemolytic toxin isolated from the a-hemolysin from Staphylococcus aureus). Each point represents the mean $\pm S D$ of $n=12$ experiments, with ${ }^{*} p<0.05$. (b) The comparative effect of different proteins at the dose of $1 \mu \mathrm{M}$. (c) Macrophage cell viability expressed as cell viability percentage; data are presented as mean \pm SEM $(n=12, p \leq 0.05)$.

The hemolysis percentage was calculated by the following formula:

Hemolysis $=\frac{(\mathrm{A} 540 \text { in the peptide solution }-\mathrm{A} 540 \text { in PBS })}{(\mathrm{A} 540 \text { in } 1 \% \text { Triton }-\mathrm{X} 100-\mathrm{A} 540 \text { in PBS })} \times 100 \%$

Figure 4 shows the measurement of CK levels after three hours of toxin injection. The analysis of the figure revealed that oshem 1 and oshem 2 induced a significant increasing of CK levels in relation to oshem purified from the first chromatography. But this myonecrotic effect was lower if compared to $\alpha$-hemolysin from Staphylococcus aureus.

\section{Conclusions}

Olindias sambaquiensis Muller, 1861 (Olindiidae) is a hydromedusae common in southern and southeastern 
Brazilian coastal regions and Atlantic coast of Argentina and Uruguay [7]. The accident caused by this jellyfish has been described as presenting mild pain, round plaques and no systemic symptoms $[1,2,20,21]$. Our results suggest that the oshem fractions exert significant pharmacological and toxic effects that can play an important role in the clinical manifestation induced by $O$. sambaquiensis.

\section{Ethics committee approval}

The present study was approved by the Committee for Ethics in Animal Experimentation on the São Paulo Experimental Coast Campus of UNESP. The animal utilization was approved by the Committee for Ethics in Animal Experimentation of the Institute of Biology, UNICAMP, certificate number 1320-1. The utilized Swiss mice were supplied by CEMIB, the Multidisciplinary Center for Biological Research of UNICAMP.

\section{Competing interests}

The authors declare that there are no competing interests.

\section{Authors' contributions}

TLP and $V H J$ were responsible for the clinical and experimental study of the venom; FJZ, SM, DOT, AFS, VCGS and SCBO carried out the immunoassays and participated in the sequence alignments; MHT was the senior author of the manuscript. All authors read and approved the final manuscript.

\section{Acknowledgments}

The authors would like to thank FAPESP (Projeto Temático Biota, 2010/50188-8), CNPq and CAPES for their funding of this research.

\section{Author details}

${ }^{1}$ São Paulo Experimental Coast Campus, São Paulo State University (UNESP Univ Estadual Paulista), São Vicente, São Paulo State, Brazil. 'Botucatu Medical School, São Paulo State University (UNESP - Univ Estadual Paulista), Botucatu, São Paulo State, Brazil. Department of Biochemistry, Institute of Biology, State University of Campinas (UNICAMP), Campinas, São Paulo State, Brazil. ${ }^{4}$ Center of Biological and Health Sciences, Mackenzie Presbyterian University, São Paulo, São Paulo State, Brazil. ${ }^{5}$ UNESP, Campus do Litoral Paulista, Unidade São Vicente, Praça Infante D. Henrique, s/n, São Vicente, SP CEP 11330-900, Brasil.

Received: 21 August 2013 Accepted: 30 January 2014

Published: 25 March 2014

\section{References}

1. Haddad V Jr, da Silveira FL, Cardoso JL, Morandini AC: A report of 49 cases of cnidarian envenoming from southeastern Brazilian coastal waters. Toxicon 2002, 40(10):1445-1450.

2. Haddad V Jr, Silveira FL, Migotto AE: Skin lesions in envenoming by cnidarians (Portuguese man-of-war and jellyfish): etiology and severity of accidents on the Brazilian Coast. Rev Inst Med Trop Sao Paulo 2010, 52(1):43-46.

3. Watson $\mathrm{GM}$, Hessinger DA: Evidence for calcium channels involved in regulating nematocyst discharge. Comp Biochem Physiol Comp Physiol 1994, 107(3):473-481.

4. Alsen C: Biological significance of peptides from Anemonia sulcata. Fed Proc 1983, 42(1):101-108.

5. Norton RS: Structure and structure-function relationships of sea anemone proteins that interact with the sodium channel. Toxicon 1991, 29(9):1051-1084.

6. Honma T, Shiomi K: Peptide toxins in sea anemones: structural and functional aspects. Mar Biotechnol (NY) 2006, 8(1):1-10.

7. Júnior MN, Haddad MA: Variações morfológicas em Olindias sambaquiensis (Cnidaria, Hidrozoa, Limnomedusae) no Litoral de Guaratuba, Paraná Brasil. Rev Bras Zool 2006, 23(3):879-882.
8. de Oliveira DG, Toyama MH, Martins AM, Havt A, Nobre AC, Marangoni S, Câmara PR, Antunes E, de Nucci G, Beliam LO, Fonteles MC, Monteiro HS: Structural and biological characterization of a crotapotin isoform isolated from Crotalus durissus cascavella venom. Toxicon 2005, 42(1):53-62.

9. Herling AW, Maas J, Seeger K: Guidelines for the care and use of laboratory animals. In Drug Discovery and Evaluation: Pharmacological Assays. Edited by Vogel HG, Vogel WH. Germany: Springer Berlin Heidelberg; 1997:726-740.

10. Passero LF, Tomokane TY, Corbett CE, Laurenti MD, Toyama MH: Comparative studies of the anti-leishmanial activity of three Crotalus durissus ssp. venoms. Parasitol Res 2007, 101(5):1365-1371.

11. Malovrh P, Sepcić K, Turk T, Macek P: Characterization of hemolytic activity of 3-alkylpyridinium polymers from the marine sponge Reniera sarai. Comp Biochem Physiol C Pharmacol Toxicol Endocrinol 1999, 124(2):221-226.

12. Martins RD, Alves RS, Martins AM, Barbosa PS, Evangelista JS, Evangelista JJ, Ximenes RM, Toyama MH, Toyama DO, Souza AJ, Orts DJ, Marangoni S, de Menezes DB, Fonteles MC, Monteiro HS: Purification and characterization of the biological effects of phospholipase $A(2)$ from sea anemone Bunodosoma caissarum. Toxicon 2009, 54(4):413-420.

13. Carneiro RF, Nascimento NR, Costa PP, Gomes VM, de Souza AJ, de Oliveira SC, Dos Santos Diz Filho EB, Zara FJ, Fonteles MC, de Oliveira Toyama D, Toyama MH, Santos CF: The extract of the jellyfish Phyllorhiza punctata promotes neurotoxic effects. J App/ Toxicol 2011, 31(8):720-729.

14. Frazão B, Vasconcelos V, Antunes A: Sea anemone (Cnidaria, Anthozoa, Actiniaria) toxins: an overview. Mar Drugs 2012, 10(8):1812-1851.

15. Anderluh G, Macek P: Cytolytic peptide and protein toxins from sea anemones (Anthozoa: Actiniaria). Toxicon 2002, 40(2):111-124.

16. Toyama MH, Toyama DO, Joazeiro PP, Carneiro EM, Beriam LO, Marangoni LS, Boschero AC: Biological and structural characterization of a new PLA2 from the Crotalus durissus collilineatus venom. Protein J 2005, 24(2):103-112.

17. Anderluh G, Macek P: Dissecting the actinoporin pore-forming mechanism. Structure 2003, 11(11):1312-1313

18. Parker MW, Feil SC: Pore-forming protein toxins: from structure to function. Prog Biophys Mol Biol 2005, 88(1):91-142.

19. Kokelj F, Mianzan H, Avian M, Burnett JW: Dermatitis due to Olindias sambaquiensis: a case report. Cutis 1993, 51(5):339-342.

20. Mianzan HW, Fenner PJ, Cornelius PF, Ramírez FC: Vinegar as a disarming agent to prevent further discharge of the nematocysts of the stinging hydromedusa Olindias sambaquiensis. Cutis 2001, 68(1):45-48.

21. Mosovich $\mathrm{JH}$, Young P: Picadura de medusa Olindias sambaquiensis: análisis de 49 casos. Medicina (B Aires) 2012, 72(5):380-388.

doi:10.1186/1678-9199-20-10

Cite this article as: Junior et al:: Identification of two novel cytolysins

from the hydrozoan Olindias sambaquiensis (Cnidaria). Journal of

Venomous Animals and Toxins including Tropical Diseases 2014 20:10.

\section{Submit your next manuscript to BioMed Central and take full advantage of:}

- Convenient online submission

- Thorough peer review

- No space constraints or color figure charges

- Immediate publication on acceptance

- Inclusion in PubMed, CAS, Scopus and Google Scholar

- Research which is freely available for redistribution 